\title{
POÉTICAS DE ARQUIVO COMO PRÁTICAS URBANAS: \\ TRÊS GESTOS DE PESQUISA NO ARQUIVO DO \\ LABORATÓRIO DE FOTODOCUMENTAÇÃO SYLVIO DE VASCONCELLOS
}

\author{
Junia Cambraia Mortimer* \\ *Universidade Federal da Bahia, Programa de Pós-graduação em Arquitetura e Urbanismo, Salvador, BA, Brasil.
}

\begin{abstract}
Resumo
Este texto apresenta três gestos de pesquisa (ampliar, desmontar e desviar) que realizamos no arquivo fotográfico do Laboratório de Fotodocumentação Sylvio de Vasconcellos, a fim de evidenciar aspectos que instituem um campo de debates em torno da cidade, da técnica e do cotidiano. Operamos com fontes provenientes do Serviço de Fotodocumentação da Escola de Arquitetura da Universidade Federal de Minas Gerais, majoritariamente dos anos de 1954 a 1964. Os gestos de pesquisa, enquanto poéticas, experimentam modos de "fazer o arquivo falar". E provocam ruídos quando colocam em discussão a vida ordinária capturada por meio da fotografia e as implicações dessa mediação técnica na prática da cidade e na construção de representações e discursos. Ao perfurarem o dispositivo do arquivo patrimonial e incidirem na trama histórica em torno do popular, esses gestos vislumbram atualizações críticas em torno do descarte e são também práticas urbanas na medida em que instauram outros modos de ver a cidade (ou des-vê-la, nos termos de Manoel de Barros e Rita Velloso).
\end{abstract}

Palavras-chave

Arquivo; Fotografia; Cidade; Técnica; Cotidiano; Desmontar; Desviar. 


\title{
POETICS OF ARCHIVE AS URBAN PRACTICES: \\ THREE RESEARCH GESTURES IN THE ARCHIVE \\ OF THE PHOTO-DOCUMENTATION LABORATORY SYLVIO DE VASCONCELLOS
}

\author{
Junia Cambraia Mortimer* \\ *Universidade Federal da Bahia, Postgraduate Program in Architecture and Urbanism, Salvador, BA, Brazil.
}

\begin{abstract}
This article presents three research gestures (enlarging, dismantling and diverting) undertaken at the photographic archive of the Sylvio de Vasconcellos Photo-Documentation Laboratory, in order to highlight aspects that have established a field of debate regarding city, technique and everyday life. This was engaged upon with sources from the Photo-Documentation Service in the School of Architecture at the Universidade Federal de Minas Gerais, chiefly from the years 1954 to 1964. The research gestures, as poetics, experimented with ways of "making the archive speak". They also provoked sounds when they brought into discussion the ordinary life captured through photography, and the implications of this technical mediation in the practice of the city and in constructing representations and discourses. By penetrating the devices of the patrimonial archive and focusing on the historical plot surrounding the vernacular, these gestures have glimpsed critical updates of what was discarded, and are also urban practices to the extent that they establish other ways with which to see the city (or un-see it, in the terms of Manoel de Barros and Rita Velloso).
\end{abstract}

Keywords

Archive, Photography, City, Technique, Everyday Life, Dismantle, Divert. 


\title{
POÉTICAS DE ARQUIVO COMO PRÁTICAS URBANAS: TRÊS GESTOS DE PESQUISA NO ARQUIVO DO LABORATÓRIO DE FOTODOCUMENTAÇÃO SYLVIO DE VASCONCELLOS
}

\author{
Junia Cambraia Mortimer
}

Introdução

O arquivo é uma brecha no tecido dos dias, a visão retraída de um fato inesperado. (FARGE, 2017, p. 15)

Há uma máquina grande e imponente instalada na última sala do espaço do Laboratório de Fotodocumentação Sylvio de Vasconcellos na Escola de Arquitetura da Universidade Federal de Minas Gerais (UFMG). Uma máquina cuja presença se

\footnotetext{
1. Este texto é fruto de estágio pós-doutoral realizado em 2019 no Programa de Pós-graduação em Arquitetura e Urbanismo da Universidade Federal de Minas Gerais (NPGAU/UFMG), sob tutela da professa Renata Marquez. O projeto de pesquisa, intitulado "Imagem, técnica, cotidiano: o arquivo do Laboratório de Fotodocumentação Sylvio de Vasconcellos”, relaciona-se a uma trajetória de investigação, por meio da qual tenho buscado explorar a imagem, o arquivo e, mais recentemente - em virtude de interlocução com o professor Eduardo Costa, da Faculdade de Arquitetura e Urbanismo da Universidade de São Paulo (FAU-USP) -, o livro, no campo da história e da teoria da arquitetura e do urbanismo. No âmbito dessa trajetória, destaco em especial dois trabalhos: o livro Arquiteturas do olhar (MORTIMER, 2017), fruto de minha tese de doutorado desenvolvida no NPGAU/UFMG; e o livro Entre imagem e escrita: Aracy Esteve Gomes e a cidade de Salvador (no prelo pela Editora da UFBA), organizado com o professor Washington Drummond, da Universidade do Estado da Bahia (Uneb), e que congregou outros pesquisadores do campo da arquitetura e do urbanismo interessados na discussão de imagem e arquivo, entre os quais Eduardo Costa (USP), Breno Silva (Instituto Federal de Educação Ciência e Tecnologia de Minas Gerais - IFMG) e Renata Marquez (UFMG), além de doutorandos e graduandos do Programa de Pós-graduação de Arquitetura e Urbanismo da Universidade Federal da Bahia (PPGAU/UFBA). Uma versão resumida do presente artigo foi apresentada na forma de conferência no $6^{\circ}$ Seminário Ibero-americano Arquitetura e Documentação, Belo Horizonte, em novembro de 2019. Agradeço ao professor Leonardo Barci Castriota, coordenador do Laboratório de Fotodocumentação, pelo apoio ao desenvolvimento deste trabalho. Foram igualmente importantes para o desenvolvimento da pesquisa da qual este artigo é fruto as experiências didáticas nas disciplinas "Práticas fotográficas" e "Imagem etc: conversas em torno da fotografia”, propostas na EA UFMG no âmbito das atividades pós-doutorais. Agradeço a Renata Marquez, Priscila Musa e Gabriela Pires pelo compartilhamento da atividade docente nessas disciplinas, e aos estudantes envolvidos.
} 
torna estranha pelas dimensões, pela tecnologia e pelo estado de abandono, num espaço transformado em depósito. Como um navio naufragado no mar das possibilidades técnicas, o corpo de ferro fundido deixa o ar dos corredores mais denso e difícil de respirar: não bem pela poeira ali acumulada, mas pela inescapável afirmação do tempo, e da fugacidade da vida humana, que aquela presença impõe. Moderna presença que remete, quase imediatamente, ao misterioso universo do conto “A estranha máquina extraviada”, do escritor José J. Veiga (2008), publicado em 1968 - uma década depois da aquisição daquele equipamento pela Escola de Arquitetura, como consta na correspondência entre a fábrica Tofot e a instituição. No conto de Veiga, a máquina surge numa tarde qualquer na principal praça de uma cidade imaginária; ninguém sabe de onde veio nem a que serve, e não há um só vestígio nos documentos da prefeitura. Mas todos se habituam com ela e a incorporam aos costumes locais, inserindo-a no cotidiano de modo a torná-la, aos poucos, presença indispensável, elemento inseparável. Alguns por ela se apaixonam, outros querem transformá-la em monumento.

A máquina, um equipamento de reprodução de fotolitos, é apenas um dos objetos, junto a diversos outros equipamentos, de câmeras a ampliadores, além de negativos, slides, ampliações fotográficas, fotolitos, impressos, correspondências e outros ofícios que constituem o arquivo do que um dia foi o Serviço de Fotodocumentação (SFD), fundado em 1954 por Sylvio de Vasconcellos, então professor da Escola de Arquitetura.

Proponho para este texto apresentar três gestos de pesquisa que realizamos nesse arquivo com o objetivo de fazer emergirem aspectos referentes à cidade, à técnica e ao cotidiano, como recorte para explorar a complexidade do moderno, com vistas a fomentar atualizações historiográficas. Cada gesto ou poética de arquivo, enquanto formas de indagação (FARGE 2017, p. 19), emitiu diferentes ruídos, dentre os quais interessam, para este trabalho, aqueles que colocam em discussão a vida ordinária capturada por meio da técnica fotográfica como prática urbana e as implicações dessa mediação técnica na compreensão da cidade. Arrisco ampliar o conceito de práticas urbanas (CERTEAU, 2009, p. 159) para incorporar os próprios gestos de pesquisa realizados, entendendo-os como práticas que instauram a cidade, ao reconfigurarem nossa compreensão do urbano, dos hábitos e dos modos a ele relacionados.

As poéticas de arquivo como práticas urbanas, conforme defendo, almejam perfurar malhas históricas constituídas em torno da técnica e do cotidiano e apresentam uma outra cidade. Os gestos de pesquisa evidenciam, nos arranjos visuais criados, a dimensão cotidiana e ordinária da vida urbana e esgarçam a trama que associou patrimônio, monumento e nação, evidenciando um isso foi 
(BARTHES, 2018, p. 68) de onde emergem nuances da história da cidade e do urbanismo brasileiros, contribuindo para sua revisão historiográfica. Trata-se de criar visualidades desviantes que, ao dar a ver práticas cotidianas de cidade, corroboram a complexidade da relação universal e local, moderno e popular (MORTIMER; SÁ, 2019), deformando noções de memória ali postuladas.

Foi fundamental para o trabalho abordar a fotografia tanto na sua dimensão documental, de evidência histórica (KOSSOY, 2009, p. 27), inserida nos discursos dos códigos culturais, como também na sua dimensão irredutível daquilo que foi, como num haikai (BARTHES, 2005): puro estado de contingências no qual se economiza a tagarelice da língua pelo silêncio. É com atenção a essa condição dúbia da fotografia e com igual cuidado aos demais documentos marginais que compõem esse arquivo fotográfico (COSTA, 2018, p. 26), dentre cartas, anotações e outros fragmentos (BENJAMIN, 2012), que divisamos singularidades, cortes e desvios. Com isso, simultaneamente reconstituímos as dimensões que inserem esse arquivo e seus fragmentos no seu tempo histórico - como o regime de visibilidade dessas fotografias, o uso documental delas, a atuação dos fotógrafos envolvidos, as possibilidades técnicas nesse período - e vislumbramos, diante dessas imagens, as fagulhas, os disparos que desviam do protocolo técnico e conceitual vigente para tornar visível o real (como observou Lacan nos seus cursos na década de 1960).

Situo ainda este texto em diálogo com o campo da cultura visual, o qual tem seus antecedentes no Brasil na década de 1980 e 1990, mas cujo enfoque na relação com o campo da arquitetura e do urbanismo é relativamente tímido no contexto brasileiro ou ainda circunscrito a uma função ilustrativa da imagem. Buscamos reafirmar a imaginação fotográfica como seara epistemológica, lugar de pensamento, sobretudo no âmbito dos estudos da cidade, e segundo uma dimensão teórica e histórica, constituindo uma encruzilhada entre os campos de conhecimento da arte, da estética, da arquitetura, do urbanismo e da história.

\section{Prolegômenos de uma pesquisa em arquivo}

No Brasil, as décadas de 1980 e, principalmente, de 1990 foram marcadas por uma virada historiográfica no campo da arquitetura e do urbanismo, proporcionada, entre outros fatores, pelo incremento de pesquisas em arquivos, renovando fontes e documentos (COSTA, 2017a, p. 261). Seguindo esse movimento de expansão e renovação historiográfica, na década de 2000 houve ampliação dos trabalhos dedicados a fontes visuais, "propondo novos caminhos e sentidos para a história urbana” (COSTA, 2017a, p. 260) e também para a história da arquitetura. A renovação documental incorporou arquivos pessoais, e hoje esses acervos de objetos, imagens, diários e cartas têm contribuído para ressituar os processos de produção do espaço por meio de práticas e hábitos urbanos reunidos nesses restos materiais. 
O uso de fontes visuais em pesquisas no campo da história da cidade e do urbanismo, no Brasil, teve importantes contribuições provenientes de outros campos, notadamente da História, dentre as quais ressaltamos Fotografia e cidade, de Vânia Carvalho e Solange Lima (1997), "Fontes visuais, cultura visual, história visual”, de Ulpiano Bezerra de Meneses (2003), e, ainda, O desafio de fazer História com imagens (2006), de Paulo Knauss. Mais recentemente, destacamos a contribuição de Iara Lis Franco Schiavinatto e Eduardo Costa, com a organização do livro Cultura visual e História (2016). Costa organizou também o dossiê "Cidade e cultura visual" (2017a) para a Revista Urbana, da Universidade Estadual de Campinas (Unicamp), e publicou os livros Arquitetura e visualidade (2017b) e Arquivo, poder, memória (2018). Essas produções intelectuais privilegiam a dimensão historiográfica na abordagem dos arquivos, documentos e fontes, primando tanto pelo rigor como pelo respeito às práticas e regras próprias a esse campo disciplinar, a História.

Em âmbito internacional, e ainda no campo da história da arquitetura e do urbanismo, há uma importante inflexão nas pesquisas em torno da imagem, ou baseado nela, com os trabalhos de Beatriz Colomina, com especial atenção para Privacy and publicity: modern architecture as mass media (1996). Vale ressaltar que Colomina foi colega, em Princeton, de Anthony Vidler, a quem interessa igualmente a relação entre imagem e arquitetura (VIDLER, 2001), numa perspectiva histórica benjaminiana. É igualmente importante mencionar as pesquisas de Claire Zimmerman (2012a; 2012b; 2014), em particular seus estudos sobre a relação visual entre James Stirling, o casal Smithson e as obras de Mies van der Rohe, assim como as de Martino Stierli, com especial atenção àquelas dedicadas ao arquivo do casal Venturi e Scott Brown (STIERLI, 2013) e ao estudo da montagem como procedimento artístico moderno inerente à condição da metrópole (STIERLI, 2018).

Ao ampliar o olhar sobre o uso de fontes ou documentos visuais para além da dimensão historiográfica, identifico ainda uma série de pesquisas que proporcionam renovações no campo teórico da arquitetura e do urbanismo, em diálogo com o campo da fotografia e das artes. Guilherme Wisnik, notadamente em seu livro Dentro do nevoeiro (2019), põe em cena um dispositivo de análise, o nevoeiro, que abre caminho para explorar a produção arquitetônica contemporânea na sua relação com a imagem. Renata Marquez, desde sua tese de doutorado, Geografias portáteis: arte e conhecimento espacial (2009), proporciona um campo de pensamento e prática da arquitetura que se expande para a dimensão investigativa da curadoria e da editoria. Por fim, Heloísa Espada (ESPADA; ALONSO, 2018), sobretudo na exposição Conflitos (2018), particularmente na publicação dela resultante, procura criar uma zona convergente entre a dimensão histórica e visual dos artefatos e das imagens. Todos os três proporcionam uma encruzilhada de pensamento entre 
espaço, imagem e história que possibilita outras reflexões, resultantes da contribuição advinda do diálogo com a arte, no campo da arquitetura e do urbanismo.

No âmbito internacional, a reflexão teórica em torno da imagem fotográfica, na fronteira com o arquivo e a arte, ganha densidade com os trabalhos de Eduardo Cadava (1997; 2014) e de Gabriela Nouzeilles (2011; 2014; 2016), com especial atenção à participação de ambos na exposição The Itinerant Languages of Photography (2014); também o espanhol Joan Fontcuberta (2010; 2012; 2016), sobretudo com suas provocações mais recentes reunidas em La fúria de las imágenes (2016), na qual avança na direção da pós-fotografia; e ainda o francês Georges Didi-Huberman (2008; 2010; 2013; 2017a; 2017b). De sua produção densa e numerosa destacam-se, de um lado, livros como $O$ que vemos, o que nos olha (2010), "fábula filosófica da experiência visual” (2010), e, de outro, o ensaio Cascas (2017a), um experimento de formulação teórica e histórica que se dá no entremeio do texto, da fotografia e da memória. Todas essas pesquisas culminam, muitas vezes, na curadoria de exposições em torno do espaço, da imagem e da história, como podemos observar, entre outras, em Levantes (2017b).

$\mathrm{Na}$ abordagem adotada neste trabalho, busco tensionar diferentes campos disciplinares - historiografia e estética -, tomando como pressuposto o limiar entre análise documental (investida de um esforço de historicidade) e recepção subjetiva (investida de uma dimensão de atemporalidade), conforme investiguei em outras oportunidades (MORTIMER, 2017; 2018a). Destaco ainda que:

Explorar a imagem como fonte para estudos no campo da arquite-
tura e do urbanismo implica se deparar com o desafio de articular
o momento histórico-cultural, ao que Roland Barthes (2018) denomi-
nou studium, com a perspectiva do sujeito, punctum. Nesse sentido,
nos colocamos diante da imagem como diante de um indício, uma
marca, um vestígio, o qual podemos situar em termos de códigos e
leituras no processo histórico, mas que, ao mesmo tempo, arrisca
desestabilizar essa mesma construção pela sua dimensão negativa:
o indecifrável e irredutível que é próprio do visível (MORTIMER;
DRUMMOND, 2020, s.p.).

Consciente dessa tensão, própria da fotografia, arrisco-me a realizar três diferentes gestos ou procedimentos de pesquisa no arquivo do Laboratório de Fotodocumentação Sylvio de Vasconcellos, os quais exploram potências e limites das fontes visuais no campo da arquitetura e do urbanismo. Esse campo de possibilidades (potências e limites) tem contornos transitórios que se reconfiguram de acordo com as demandas e regras disciplinares às quais essas imagens são submetidas, enquanto fontes e/ou objeto de pesquisa. Ele compõe, assim, um enquadra- 
mento ou mesmo um regime de visibilidade (disciplinar) para as imagens dentro do processo de pesquisa, ao condicionar a utilização de dada fonte. Isso significa que os regimes de visibilidade que condicionam o aparecimento e a circulação das imagens são forjados, primeiro, pelos meios técnicos disponíveis que produzem a matriz documental; e, segundo, pelos códigos disciplinares às quais elas se submetem como material de pesquisa. Interessa a este trabalho a tensão entre o esforço historiográfico e o vislumbre estético, entre a horizontalidade da trama narrativa e a verticalidade da experiência sensível. É nesse limiar onde, acredito, reside uma possibilidade para a reinvenção das imagens.

1.1 Descrição do arquivo do Laboratório de Fotodocumentação Sylvio de Vasconcellos

O Laboratório de Fotodocumentação Sylvio de Vasconcellos ocupa hoje um espaço na Escola de Arquitetura da UFMG que reúne os vestígios de dois importantes serviços que se desenvolveram nessa instituição, muito ativamente na década de 1960: o Serviço de Fotodocumentação e o Serviço Gráfico. O arquivo compreende negativos, diapositivos, ampliações fotográficas, fotolitos, equipamentos fotográficos, e ainda correspondências, relatórios, manuais instrutivos, cadernos de registro, envelopes classificatórios, além de mobiliário (Figura 1).
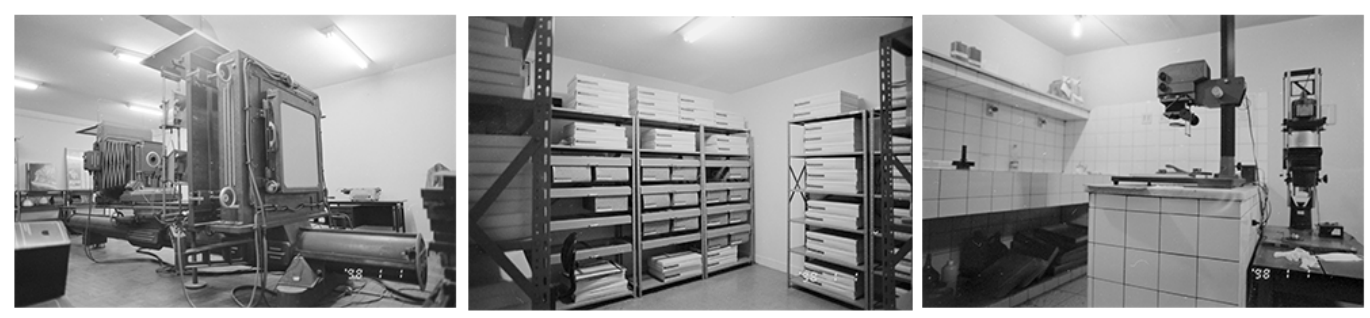

Figura 1. Salas do Laboratório de Fotodocumentação Sylvio de Vasconcellos

Da esquerda para a direita: sala onde se localiza a máquina de reprodução de fotolitos; sala de climatização do acervo imagético do Laboratório de Fotodocumentação Sylvio de Vasconcellos; laboratório fotográfico analógico. Fotografias realizadas com câmera Nikon F8o e filme P\&B vencido, ambos do acervo da Escola de Arquitetura.

Fonte: Junia Mortimer, 2019.

O Serviço de Fotodocumentação foi criado em 1954, sob direção de Sylvio de Vasconcellos (1916-1979), arquiteto e intelectual mineiro, "com o objetivo de documentar fotograficamente o acervo arquitetônico e artístico de Minas Gerais” (CASTRIOTA; ÂNGELO, 2011, p. 145). O setor ficou sob a direção de Vasconcellos até 1969, mas cinco anos antes, em 1964, o professor havia sido destituído de muitas funções, como a própria direção da Escola de Arquitetura, em função do golpe civil-militar daquele ano. Esse fato reduziu sua atuação no Serviço de Fotodocumentação, cuja chefia foi atribuída a diferentes responsáveis. De meados da década de 1950 até 
meados de 1960, período em que Sylvio de Vasconcellos esteve mais ativo no setor, constam como principais profissionais do Laboratório o cinetécnico Marcos de Carvalho Mazzoni, o fotógrafo Gui Tarcísio Mazzoni e a laboratorista Efigênia Chaves.

Ao objetivo documental do patrimônio arquitetônico e artístico de Minas Gerais acrescentam-se os objetivos de registro da vida institucional da Escola e da Universidade, o apoio às atividades docentes e a prestação de serviços, sobretudo de ampliação. É sabido que o Serviço de Fotodocumentação operava em estreita relação com os serviços gráficos existentes na mesma época para a produção das Edições Escola de Arquitetura. Segundo Castriota e Ângelo, as Edições teriam publicado 67 títulos entre 1961 e 1963. Explica-se com isso a presença de milhares de fragmentos de fotolitos no acervo de fotodocumentação ${ }^{2}$.

\section{Poéticas de arquivo enquanto práticas urbanas}

Colocar-se diante de um arquivo fotográfico, ora como fonte para a construção de uma narrativa, ora como o próprio objeto de investigação - no campo da arquitetura e do urbanismo -, implica explorar, segundo a abordagem que aqui construímos, no mínimo duas dimensões disciplinares: aquela da historiografia do urbano e aquela da estética. O que as diferenciou, no nosso caso, foram os modos como as visualidades criadas com os documentos - arranjos visuais provisórios - mobilizaram distintamente teorias e narrativas historiográficas já constituídas.

Algumas visualidades, pela insuficiência das informações indexadas aos documentos encontrados, assumem uma dimensão estética na medida em que proporcionam uma reflexão em torno da história da cidade, por meio do universo fotográfico, de maneira concentrada e vertical; mais abissal do que sequencial (NAVAS, 2018, p. 21). Nessas visualidades, há um jogo entre presença e ausência, visível e invisível, cuja existência se dá "no curso de uma construção sobre o mesmo lugar, como a arquitetura é capaz de fazer” (NAVAS, 2018, p. 21).

Outras visualidades, ao contrário, arrogam uma dimensão historiográfica quando, ao arranjarem os documentos encontrados numa trama complexa de acontecimentos, sobretudo relacionadas à história da cidade de Belo Horizonte, produzem uma relação duradoura entre a materialidade e a narrativa que se quer produzir.

\footnotetext{
2. $\mathrm{O}$ acervo do SFD - nomeadamente os negativos $35 \mathrm{~mm}$ e $120 \mathrm{~mm}$, os fotolitos e as ampliações de época - foi objeto de projetos de digitalização e preservação aprovados entre 2003 e 2007 junto à Fundação de Amparo à Pesquisa do Estado de Minas Gerais (Fapemig), ao Fundo Municipal de Cultura, à Caixa Econômica Federal e à Petrobras, que possibilitaram "digitalizar mais de 25.000 imagens", além de desenvolver um "sistema de recuperação física do acervo, com um novo acondicionamento e a construção de uma sala climatizada” (CASTRIOTA; ÂNGELO, 2011, p. 145).
} 
Os três gestos de pesquisa que vou apresentar são: ampliar, desmontar e desviar. A principal razão de me debruçar sobre eles, dentre outros que realizei no processo, consiste no fato de evidenciarem limites metodológicos em tentar fazer "falar" o arquivo ${ }^{3}$. Ao mesmo tempo, tais gestos potencializam um jogo entre diferentes regimes de visibilidade (ou enquadramentos disciplinares) para os documentos, os quais ora seguem, ora não, as regras da narrativa historiográfica. No limiar entre punctum e studium (BARTHES, 2018), entre a verticalidade do abissal e a horizontalidade da trama (NAVAS, 2018), esses procedimentos esboçam percursos a serem seguidos ao se pesquisar arquivos fotográficos, mas não se cristalizam enquanto métodos. São gestos transitórios que, situados nesta pesquisa, possibilitaram fomentar o debate em torno de cidade, técnica e cotidiano, nas décadas de 1950 e 1960, e ainda atualizar essa discussão para a cidade contemporânea. Nesse sentido, argumento que são práticas urbanas, ao considerar que a dimensão urbana não se restringe às atividades da esfera pública; e que pequenos gestos, sobreviventes à luz fria de uma sala de climatização, ao serem narrados, colocam em movimento cidade, sujeitos, hábitos e modos de vida.

\subsection{Ampliar: gestos urbanos ${ }^{4}$ na coleção de diapositivos}

Como todo aspirante a historiador, pelo menos aqueles de vertente benjaminiana e que se debruçam sobre material visual (BENJAMIN, 2017a, 2017b), ao me aproximar desse arquivo, fui em busca de fragmentos, restos, sobras, fiapos. Sabendo que mais de 20 mil negativos haviam sido digitalizados e disponibilizados online, procurei por aquilo que estava fora desse escopo. E encontrei a imensidão de um extracampo que constitui toda e qualquer imagem. Foquei o extracampo das fontes visuais que haviam sido digitalizadas, e fui primeiramente seduzida por uma pequena coleção de diapositivos.

Talvez pela presença da cor, depois de finalizar um longo trabalho de pesquisa na minha universidade de origem com um arquivo fotográfico em preto e bran$\mathrm{co}^{5}$; talvez pelo aspecto agradável dos slides sobre a mesa de luz. Talvez simples-

3. Vale mencionar, ainda, que a ausência de minuciosos roteiros fotográficos e a presença de inesperados documentos de outra natureza no arquivo deslocaram nosso foco da operação fotográfica protocolar, muito bem estudada por outros autores (COSTA, 2018), a fim de priorizar desvios e jeitos de fazê-los emergir na pesquisa de arquivo, atribuindo uma dimensão metodológica ao trabalho.

4. A utilização do termo "gestos urbanos" remete ao trabalho desenvolvido pelo grupo de pesquisa Laboratório Urbano no evento Corpocidade 5, ocorrido em dezembro de 2016, edição dedicada ao tema. Para saber mais, ver: JACQUES, P.; BRITTO, F. Gestos urbanos. Salvador: Edufba, 2017

5. Refiro-me ao projeto de pesquisa "Imaginários e visibilidades: práticas urbanas em fotografias soteropolitanas (1950-1970)", dedicado ao acervo da professora de matemática e fotógrafa amadora Aracy Esteve Gomes, em Salvador. O resultado dessa pesquisa será publicado no livro Entre imagem e escrita: Aracy Esteve Gomes e a cidade de Salvador (no prelo pela Edufba, 2020), organizado por mim e pelo professor Washington Drummond. 
mente pela dimensão reduzida dessa coleção, que não chega a 3 mil imagens - um número mais palatável que as dezenas de milhares dos fotolitos, ou dos negativos. Talvez por tudo isso junto. Escolhi aquele como um dos caminhos de entrada.

Com os diapositivos sobre a mesa de luz, passei alguns dias a observar cada uma das imagens. Perscrutava os edifícios, os ângulos, as cores, o estado das películas; imaginava lugares, câmeras e possíveis temporalidades. Confesso que não consegui parar de ver os slides, folha após folha, pasta após pasta, até terminá-los todos. Imediatamente percebi algumas presenças que chamaram mais minha atenção: pequenos gestos urbanos, capturados no meio da cidade, mas de dimensão quase privada ou íntima, insurgiam entre as edificações, entre os detalhes construtivos, entre a imaginária. Ampliei-os com lupa para ver melhor (Figura 2).

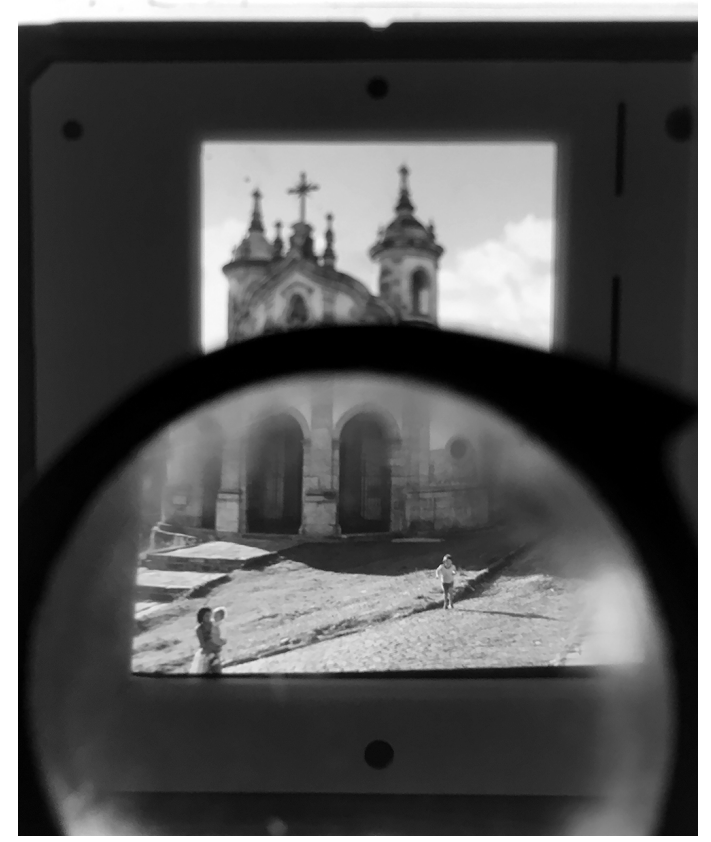

Figura 2. Da série "O que vemos, quem nos olha" Fotografias de diapositivos sobre mesa de luz. Fonte: Junia Mortimer, 2019.

Quem me olhava? Alguns sujeitos, fotografados talvez inadvertidamente, inquiriam-me sobre o meu gesto de pesquisa. Depois de uma espécie de fruição intensiva desse conjunto de imagens, procurei por informações que me possibilitassem situar aquela coleção, identificar datas, localizações geográficas, monumentos, pessoas etc. Para o desespero de uma pesquisadora - ou seria o avesso do avesso da sorte? -, não havia nenhuma indexação daquelas imagens no arquivo. Diante da 
improbabilidade de conclusão de um trabalho historiográfico dentro dos prazos do projeto em curso, permiti-me apenas ver tudo aquilo e perceber quem me olhava: aceitei a limitação daquelas fontes para aquele momento da investigação. Aproveitei delas a possibilidade de associar gesto de pesquisa à poética, ao fazer estético, e dessa primeira prática de arquivo resultou um conjunto de imagens ${ }^{6}$ fotográficas, às quais intitulei “O que vemos, quem nos olha” (2019), em referência ao título do livro de Georges Didi-Huberman, mencionado na primeira parte deste artigo. Como argumenta o autor (2010, p. 34): "abramos os olhos para experimentar o que não vemos, o que não mais veremos - ou melhor, para experimentar que o que não vemos com toda a evidência (a evidência visível) não obstante nos olha como uma obra (uma obra visual) de perda" (Figuras 3 e 4).

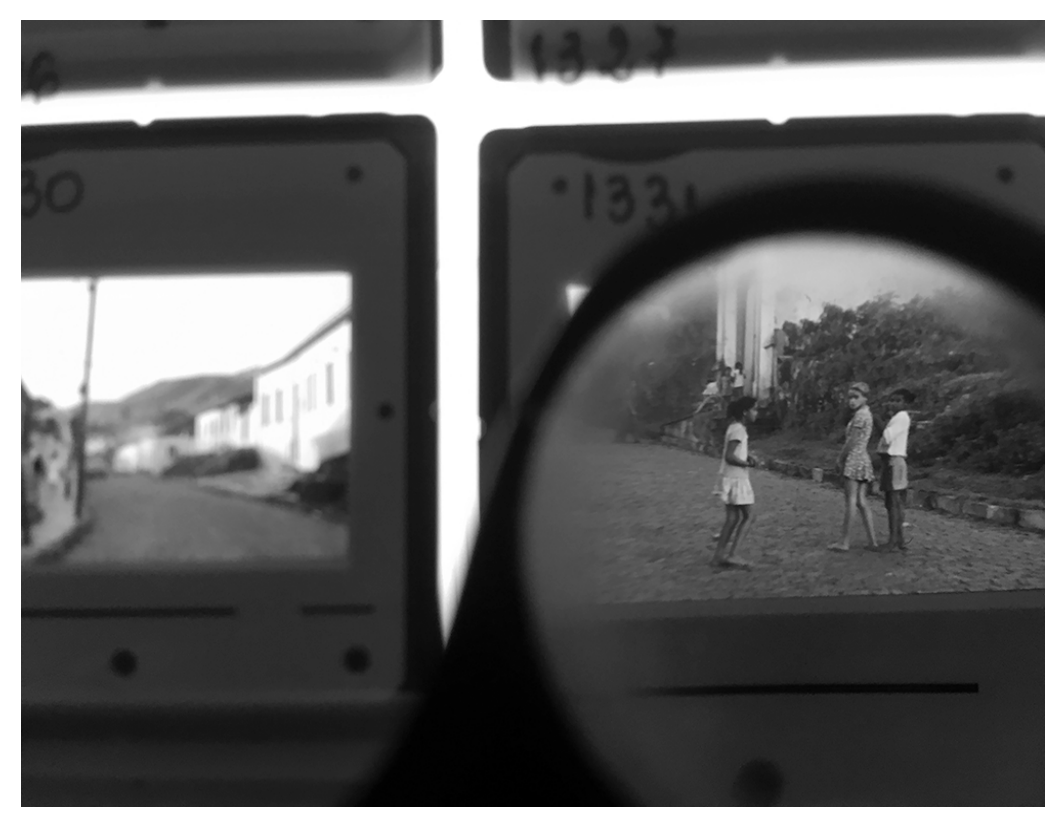

Figura 3. Da série "O que vemos, quem nos olha" Fotografias de diapositivos sobre mesa de luz. Fonte: Junia Mortimer, 2019.

Não foi por meio dessa série que prossegui com o empreendimento de uma narrativa historiográfica em torno de cidade, técnica e cotidiano, pois isso se tornou inviável dentro dos prazos de que dispunha. Mas foi esse conjunto de imagens

6. Intitulei esse conjunto de imagens "O que vemos, quem nos olha”, em referência ao título do livro de Georges Didi-Huberman, o que vemos, o que nos olha (2010), que reúne diferentes ensaios em torno da visualidade, segundo uma perspectiva marcadamente lacaniana (sobretudo os fundamentos psicanalíticos da teoria do espelho e o clássico episódio da lata de sardinha) (LACAN, 1978). LACAN, J. The four fundamental concepts of Psychoanalysis. Edited by Jacques-Alain Miller. Translated by Alan Sheridan. New York: W. W. Norton \& Company, 1978. 
que possibilitou ampliar de modo inquiridor os horizontes e a imaginação sobre memória, sujeitos e patrimônio; sobre os processos de escolha na constituição do arquivo enquanto dispositivo de poder, como incansavelmente explora Ariella Azoulay (2019); sobre o que e sobre quem estava autorizado a aparecer naquelas imagens documentais. Deixei-as, as imagens da série, reservadas para investigações futuras, regidas por outras temporalidades. E resolvi, então, debruçar-me sobre a principal fonte desse arquivo fotográfico, os negativos de médio formato. Com isso, passo ao próximo gesto de pesquisa a ser apresentado neste texto.

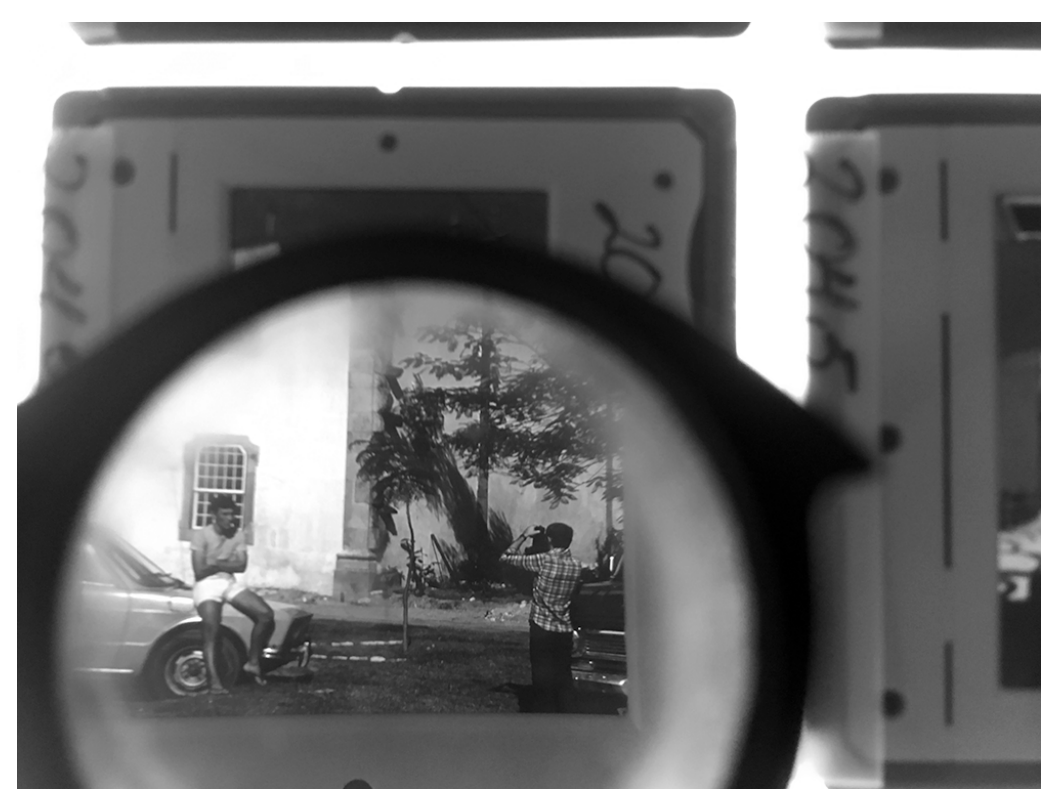

Figura 4. Da série "O que vemos, quem nos olha" Fotografias de diapositivos sobre mesa de luz. Fonte: Junia Mortimer, 2019.

\subsection{Desmontar: disputas urbanas no fascículo fotográfico Documentário Arquitetônico 3 (1961)}

Detive-me nos negativos de $120 \mathrm{~mm}$ e repassei na mesa de luz cerca de $17 \mathrm{mil}$ fotogramas. Olhei-os acompanhada dos três tomos de livros de registro, confeccionados posteriormente à realização das fotografias, mas cuja forma de organização guiou a identificação das digitalizações realizadas na primeira década do século XXI, como confirmou Carla Viviane Ângelo (CASTRIOTA; ÂNGELO, 2011, p. 145-182), cientista da informação que acompanhou a pesquisa arquivística e o trabalho catalográfico nos projetos empreendidos na década de 2000.

Entre profetas, frontões, balaustradas, forros, cantarias, varandas, cruzeiros, igrejas, sanatórios, telhados borboleta, curvas de concreto, cartazes estudantis contra o golpe (aquele de 1964 e não este de 2016), cerimônias acadêmicas ou mesmo 
a visita da miss Minas Gerais às dependências da Escola de Arquitetura da UFMG, em 1963, e outras tantas imagens, um conjunto específico chama atenção (Figura 5).
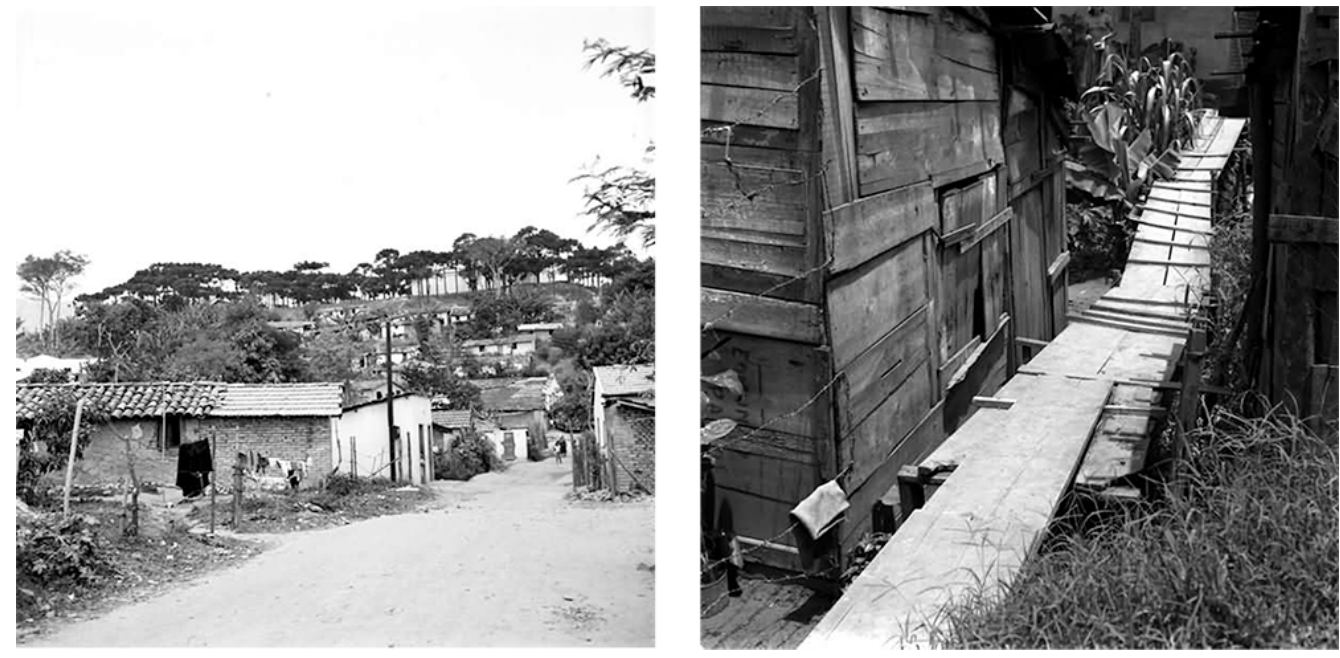

Figura 5. Fotografias de Gui Tarcísio Mazzoni e Marcos Mazzoni presentes no arquivo do Laboratório Sylvio de Vasconcellos (1961)

Fonte: Gui Tarcísio Mazzoni e Marcos Mazzoni, 1961.

Nele, vemos sujeitos pobres e arquiteturas populares, fotografadas segundo os padrões técnicos das fotografias patrimoniais. No livro de registros, essas fotografias, junto com as demais que compõem esse conjunto, concernem ao espaço das favelas Pindura Saia, Ilha dos Urubus, Av. Bias Fortes e assentamento dos Vagões. Todas as fotografias foram realizadas em Belo Horizonte, em 1961, e nenhuma dessas favelas existe mais. O que teria movido os fotógrafos daquele laboratório, aparentemente dedicado a outras situações socioespaciais, a fotografar tais favelas? Onde essas imagens teriam sido utilizadas? Como teriam circulado? E segundo qual regime de visibilidade?

$\mathrm{Na}$ montagem de uma das páginas do Documentário Arquitetônico 3 (Figura 6), dedicada à favela Pindura Saia, três fotografias situam o leitor no ambiente urbano em estudo, desde um ângulo mais aberto, distanciado, até tomadas mais próximas e fechadas nas edificações. As legendas informam sobre a construção das moradias, indicando fases do processo, e a incorporação de novos materiais. Em uma delas, lemos: "Residência de alvenaria de tijolo de duas fases de construção, sendo a primeira coberta com telha 'canal' e a segunda, com telhas 'francesas”' (MAZZONI; MAZZONI, 1961, s.p.). As fotografias denotam conhecimento técnico de representação da arquitetura e adequado balanço de luz. Elas também fornecem informações sobre a urbanidade característica desse espaço, constituído em torno de vias de chão batido e decorado com roupas penduradas nas cercas. 
Em destaque, na parte superior direita da página, espaço privilegiado no ato de leitura ocidental, está escrito: “Os bons eu enalteço, os maus eu critico. Devo reservar as palavras suaves para os operários, para os mendigos, para os escravos da miséria”. É uma citação de Carolina Maria de Jesus, de seu livro Quarto de despejo: diário de uma favelada, cuja primeira publicação é de 1960, apenas um ano antes desse documentário. Eis que encontramos um dos lugares por onde circularam as fotografias improváveis àquele arquivo.

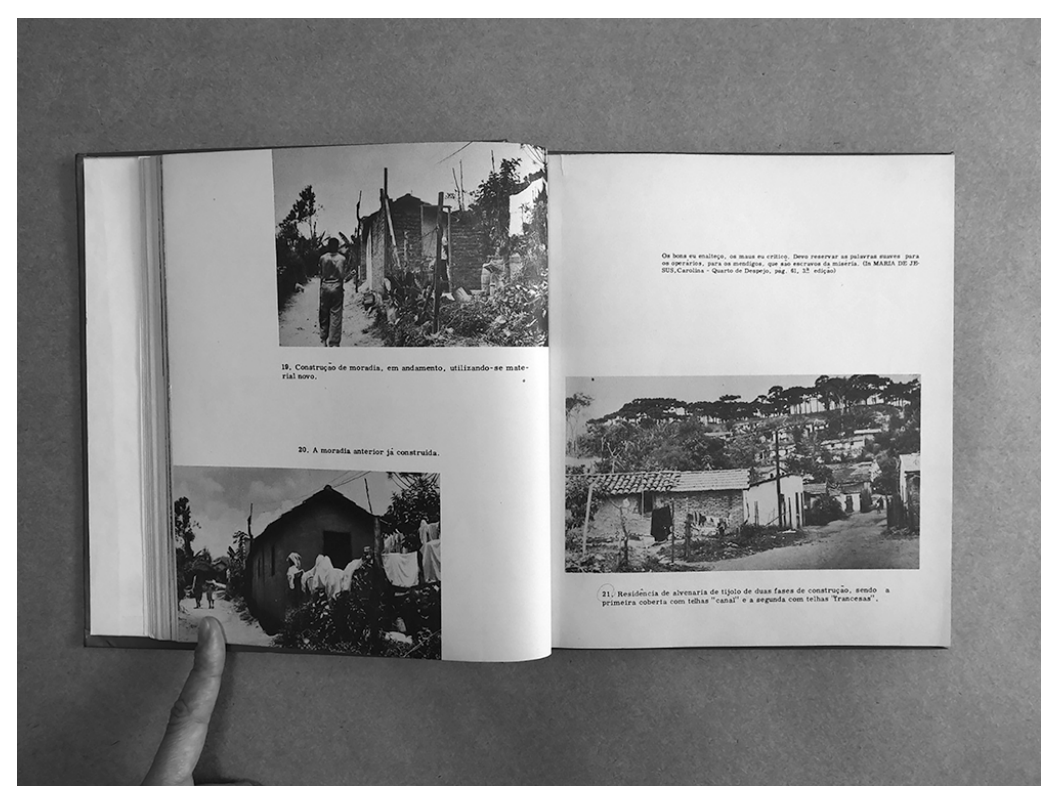

Figura 6. Documentário arquitetônico 3

Fonte: Junia Mortimer, 2019.

A série de fascículos fotográficos intitulada Documentário Arquitetônico resultou de uma parceria entre o Serviço de Fotodocumentação e o Serviço Gráfico da Escola da Escola de Arquitetura da UFMG7 ${ }^{7}$, com a produção de mais de sessenta títulos ${ }^{8}$, entre trabalhos dos professores da casa, traduções e algumas prestações de serviço. (Figura 7).

7. Os fotolitos presentes na sala de climatização, bem como a máquina de reprografia que ocupa a última sala do espaço do Laboratório, são vestígios do Serviço Gráfico que foi prestado na Escola de Arquitetura paralelamente ao Serviço de Fotodocumentação. Há sobreposição da atuação desses dois setores, mas consta nos documentos que, durante o período que este estudo cobre, 1954 a 1969, eles eram independentes e teriam sido submetidos, em 1963, com a Seção de Pesquisa, ao Instituto Superior de Pesquisa em Planejamento (ISPPLA), desmontado pelo golpe civil-militar de 1964.

8. Entre esses títulos, encontramos, por exemplo, os ambiciosos dez volumes da História da Arquitetura, de João Boltshauser, além de suas Noções de evolução urbana das Américas; encontramos também uma tradução da Carta de Atenas, de Le Corbusier, publicada pelo Diretório Acadêmico 

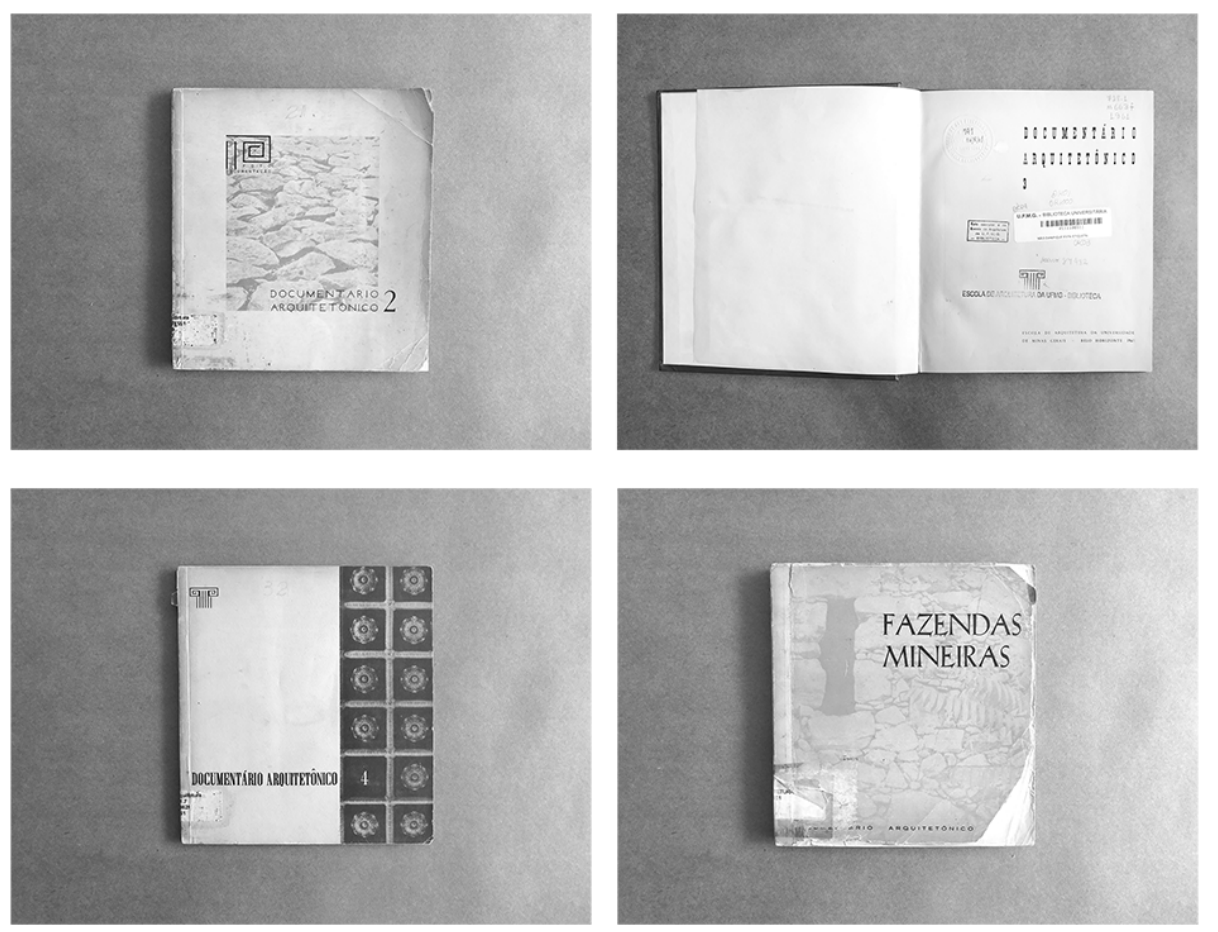

Figura 7. Capa das edições da série Documentários Arquitetônicos números 2, 4, 5 e 6, publicados pelo Serviço Gráfico da Escola de Arquitetura da UFGM, em parceria com o Serviço de Fotodocumentação (1961 a 1969)

Fonte: Junia Mortimer, 2019.

O tema do Documentário Arquitetônico 3 - "Favelas" - sucedia "Pavimentação" (WASNER, 1960), tema do número 2, e antecedia "Forros” (BRITO; STRAMBI, 1961), tema do número 4; tem-se aí uma sequência bastante singular: como esse complexo tema socioespacial teria se infiltrado entre esses dois fragmentos tipológicos, de componentes arquitetônicos - forros - ou urbanos - pavimentos? Além desses, os outros temas publicados foram "Alpendres” (PINHEIRO; MAZZONI; MAZZONI, 1960), tema do primeiro número; "Primeiras casas de Belo Horizonte" (MOURA, 1961), da edição de número 5, e, por fim, "Fazendas mineiras" (MENEZES, 1969), fechando a série. Geralmente, cada edição ficava sob a responsabilidade de um professor. Favelas, por exemplo, havia ficado a cargo do fotógrafo Gui Tarcísio Mazzoni e do cinetécnico Marcos Mazzoni, do Serviço de Fotodocumentação. A professora Suzy de Mello, autora do texto de apresentação desse volume, salienta: “A par de seu belo trabalho fotográfico, foram eles também responsáveis pelos comentários e legendas que enriquecem esse volume, complementando-o ainda com leis e decretos referentes ao tema ao qual tanto se dedicaram" (MELLO, 1961, s.p.). 
Ainda para Suzy, esse estudo procura, sem pretensões, "registrar, principalmente, algumas soluções construtivas adotadas pelos favelados, as quais - pelo seu pitoresco, engenho e mesmo pureza - justificam uma publicação como esta" (MELLO, 1961, p. 1). O campo semântico criado em torno dos termos "engenho", "pitoresco" e, especialmente, "pureza” situam essa fala numa perspectiva entre admiração genuína entusiasta e populismo político.

Essa parte do texto de Suzy remete-nos ao debate em torno do popular, tão presente nesse momento histórico, como, por exemplo, na exposição Architecture without Architects, realizada no Museu de Arte Moderna de Nova York (MoMA), em 1964, por Bernard Rudofsky, ou, ainda, nas exposições organizadas pela arquiteta ítalo-brasileira Lina Bo Bardi, a exemplo de Bahia (1959), que teve lugar no Ibirapuera, e Nordeste (1963), no Museu de Arte Popular de Salvador, inaugurando o Solar do Unhão. Na função de diretora do Museu de Arte Moderna da Bahia, Lina Bo Bardi fomentou intensamente a reflexão sobre a distinção presente no circuito artístico da arte dita erudita e da arte popular e atuou de modo a valorizar os artefatos populares nordestinos. Isso lhe rendeu duras críticas do economista Celso Furtado, responsável na época pela Superintendência do Desenvolvimento do Nordeste (Sudene). Os dois acabaram por se entender quando ficou nítido que partilhavam a mesma postura desenvolvimentista da esquerda e apoiavam, evidentemente, os processos de mecanização do campo e de industrialização das cidades, por meio da Sudene - os mesmos que incidiriam sobre os hábitos e culturas das populações nordestinas. Mas a Lina interessava, de fato, a sobrevivência de uma poética do popular, ainda que dentro de outros processos produtivos - o que não era uma questão para Furtado naquele momento. Podemos identificar a tensão entre arcaico e cosmopolita, popular e moderno em inúmeras outras produções artísticas e intelectuais do período, de Paul Ricoeur a Ferreira Gullar, passando por Glauber Rocha, Jorge Amado e Pierre Verger.

No caso de Suzy de Mello, a admiração pelo engenho vem necessariamente associada a um pesar pelas condições de vida daquelas populações: "Entre as favelas de Belo Horizonte", ela prossegue, os Mazzoni "escolheram três que, por suas características, representam bem alguns dos aspectos encontrados nesse triste tipo de aglomeração humana”. Continuando, Suzy apresenta a assistente social do Departamento de Habitação e Bairros Populares (DBP), da Prefeitura de Belo Horizonte, Catarina van Brederode, como a voz técnica que completa aquela edição com "ampla explanação sobre o problema das favelas".

O DBP, ao qual estava vinculada a assistente social Catarina van Brederode, foi criado em 1955, na gestão do prefeito Celso Mello de Azevedo, como medida sugerida pela Comissão de Desfavelamento, esta, por sua vez, criada no mesmo ano 
"com o objetivo de cadastrá-las [as favelas] e propor políticas para a solução do problema” (SOMARRIBA; VALADARES; AFONSO, 1984, p. 40). As ações do DBP eram, no entanto, pautadas pela seguinte imaginação social: "O órgão atingiria a população 'marginal', integrando-as à sociedade com obras assistenciais (atendimentos médicos e odontológicos, cursos profissionalizantes etc.) e com a construção de moradias higiênicas” (OLIVEIRA, 2012, p. 107). Nesse sentido, o movimento de favelas daquele momento, segundo o pesquisador Samuel Oliveira, opunha-se "à gestão do território encaminhada pela prefeitura”. Os movimentos não concordavam com a ideia de desfavelamento, mas o "DBP ofereceu inúmeras oportunidades políticas para a negociação de benefícios” (OLIVEIRA, 2012, p. 110).

Na sequência do texto de Introdução escrito pela assistente social do DBP, o Documentário organiza-se em cinco partes, quatro delas dedicadas aos territórios fotografados e um apêndice. Entre os documentos contidos nesta última parte estão, na íntegra, as leis de criação (1955) e de estruturação (1956) do DBP, bem como o regulamento e modificações decretadas posteriormente. Em seguida, constam o regulamento do Departamento Municipal da Casa Popular, de Porto Alegre, experiência que inspirou a criação do DBP, e leis subsequentes para implementar seu funcionamento na capital do Rio Grande do Sul. Por fim, há ainda um Código de Honra, elaborado pelo bispo auxiliar do Rio de Janeiro, Dom Hélder Câmara, no contexto da Cruzada São Sebastião, na década de 1950, destinado aos favelados nos termos do autor - e dividido em normas para homens, mulheres e crianças.

As quatro partes do fascículo referentes aos territórios fotografados estruturam-se segundo um breve texto, também de autoria dos fotógrafos do SFD, que localiza historicamente a favela em estudo e fornece alguns dados gerais, acompanhado de um mapa de localização. Na sequência, fotografias, legendas e citações configuram os ensaios dedicados a cada favela separadamente. Nessa parte do documento, como sugerido pela montagem anteriormente apresentada, a tônica do discurso se altera. O que era exceção - despontam por vezes o engenho e o arranjo curioso - torna-se regra; assume centralidade a agência construtiva diante da urgente pulsão da vida. A abordagem visual tipológica das edificações, que segue a prática fotográfica arquitetônica, sobretudo aquela dos roteiros patrimoniais, muito praticada pelos fotógrafos do SFD, é complementada por legendas que descrevem tecnicamente e segundo terminologias próprias do campo as soluções construtivas apresentadas. A título de exemplo, em outra montagem do Documentário, referente à favela da avenida Bias Fortes, lemos: "Construção recente com tábuas de forma colocadas horizontalmente, com mata-juntas de ripas de diferentes larguras. Na fachada principal as tábuas estão sem sentido vertical. Meia-água de telhas 'francesas'. O eixo da cancela do terreiro tem como apoio um fundo côncavo de garrafa” (MAZZONI; MAZZONI, 1961, s.p.). 
Como técnicos, os fotógrafos, de fato, escrutinaram aqueles lugares, aquelas pessoas - mas não sem resistência: o simples gesto de virar o rosto no momento da tomada da foto é já um gesto de resistência. No entanto, permito-me pensar também que as fotografias, ou, antes, as montagens elaboradas com essas fotografias para o fascículo de Documentário Arquitetônico 3, incluindo legendas e citações literárias, apresentam algo que escapa ao discurso técnico de desfavelamento do DBP. As montagens pautam a engenhosidade inventiva daquela cultura construtiva, trazendo a habilidade de desviar a matéria do lixo para a construção do novo ao cerne de um debate marcado por discursos desqualificadores, física e moralmente, dos lugares e moradores. Há ali uma potência para mudar o discurso de estigmatização, há matéria para trabalhar o orgulho de ser morador da favela, sem negar, contudo, por exemplo, a necessidade de assistência diante da proximidade com o esgoto e do número de doentes. Além do elogio ao desvio do descarte, percebo, por meio dos excertos do livro de Carolina Maria de Jesus, um movimento de singularização de trajetórias que se desvia da generalização, da diluição completa dos corpos e das subjetividades em meras categorias demográficas populacionais.

Em 1961, mesmo ano de publicação do Documentário, a prefeitura “investiu na remoção dos moradores da Vila Pindura Saia e de outras comunidades, no intento de acelerar o programa de desfavelamento" (OLIVEIRA, 2012, p. 116). Segundo o pesquisador Samuel Oliveira, a investida gerou reações. E as passeatas contra o despejo coletivo de favelas evidenciaram as disputas, barganhas, estratégias e táticas necessariamente implicadas na aproximação entre os movimentos sociais, como a Federação dos Trabalhadores Favelados de Belo Horizonte (FTFBH), e o poder público (OLIVEIRA, 2012). Talvez as fotografias e montagens dos Mazzoni tenham surgido nesse contexto: se a estratégia, nos termos de Michel de Certeau (2009), dos dirigentes do DBP era falar de desfavelização, os movimentos, como é o caso da FTFBH, taticamente aceitavam a política para conseguir novos postos de saúde e sedes de trabalho; se a estratégia da assistente do DBP, Catarina van Brederode, era falar de humanização, higienização e padrões construtivos de novos prédios, os fotógrafos do SFD taticamente evidenciaram a potente cultura construtiva daqueles sujeitos. De modo semelhante, se a estratégia dos Mazzoni era registrar aqueles edifícios pobres e aquelas condições de urbanidade para fins de constituição do arquivo do SFD, taticamente os moradores das favelas se aproveitaram da visibilidade proporcionada, tecnicamente romantizada, para disputar novas bicas d'água ou outros aportes assistencialistas, viabilizados pelo DBP, como aqueles que aparecem nas fotografias.

Assombra, entretanto, a hipótese de que o Documentário Arquitetônico 3 tenha contribuído para a erradicação desses quatro aglomerados, que já não existem mais. Alguns desconfiam também de que o livro de Carolina Maria de Jesus, o mes- 
mo cujos excertos aparecem nas páginas do Documentário, possa ter servido para embasar argumentos favoráveis à urbanização, justificando, contrariamente ao imaginado, o despejo dos moradores da favela do Canindé, onde ela residia. Talvez um dia, seja possível elucidar completamente essa ambiguidade, com aprofundamentos futuros de pesquisa. Pode também ser que se trate apenas da condição de existência daquele trabalho, ele próprio integrante de uma série, e de um arquivo, e ao mesmo tempo um seu desmonte.

Desmontar o Documentário 3, por onde circularam alguns dos raros e preciosos negativos que registraram quatro favelas de Belo Horizonte em 1961, fez emergir a complexidade da trama na qual se envolviam a prática fotográfica, editorial e arquivística e a prática popular e cotidiana da cidade. Diante da condição ambígua das imagens, fomos instados, como derradeiro gesto de pesquisa, a explorar deslocamentos anunciados naquelas fotografias e na própria presença delas no arquivo. Num desvio de tempo e espaço, que desafiou a situação da pesquisa, levamos o arquivo para a cidade, hoje.

\subsection{Desviar: os catadores e eu ${ }^{9}$}

Sobre uma lona azul de proteção de piscina e alguns pedaços largos de papelão, Odilon Tavares dispõe sua generosa coleção de livros usados. Ele não sabe precisar o número exato, mas certamente são mais de 2 mil títulos, segundo a contabilidade de uma reportagem do jornal $O$ Tempo ${ }^{10}$, em sua edição de 2 de novembro de 2018, a propósito do recolhimento por fiscais da prefeitura de cerca de metade do material daquele sebo a céu aberto. "Eles chegaram aqui, colocaram meus livros em sacos, jogaram dentro de uma Kombi. Uma das fiscais disse que eu teria que pagar uma multa de 1.500 reais para ter meus livros de volta e que, se eu continuar aqui, viriam buscar os que sobraram”, disse Odilon na reportagem. (Figura 8)

Odilon comercializa livros encontrados no lixo ao preço fixo de cinco reais. Ele monta diariamente seu sebo na esquina da rua Grão Mogol com a avenida Contorno, em Belo Horizonte, na região Centro-Sul da cidade, marcadamente de classe média, média-alta. Sua montagem é aleatória e promove aproximações impensadas. Segundo o livreiro ${ }^{11}$, são as surpresas do lixo o que mais o atraem na profissão

9. Faço aqui explícita referência ao título do documentário de Agnés Varda, na sua tradução para o português: Os catadores e eu. Direção e roteiro: Agnés Varda, 2000. (78 min).

10. Fiscais da PBH levam 2.000 livros de vendedor. Jornal O Tempo, 2 nov. 2018. Disponível em: https://www.otempo.com.br/cidades/fiscais-da-pbh-levam-2-00o-livros-de-vendedor-1.2062985. Acesso em: 10 jul. 2020.

11. Em novembro de 2019, aumentei a assiduidade ao sebo de rua de Odilon e mantive uma série de conversas com o livreiro, as quais resultaram na série "Desvios do descarte", base para elaborar o terceiro gesto de pesquisa apresentado. 
de catador, embora a condição de trabalho seja injusta, dados os preços de aluguel dos veículos de tração oferecidos (entre um e dois mil reais). Também por isso, ele decidiu focar nos livros. Além daqueles que expõe e guarda na calçada da rua, com outros materiais coletados pelo amigo Horácio, também catador, Odilon mostra fotografias das inúmeras estantes de livro em sua casa: até hoje nunca contabilizou seu acervo. (Figura 9)
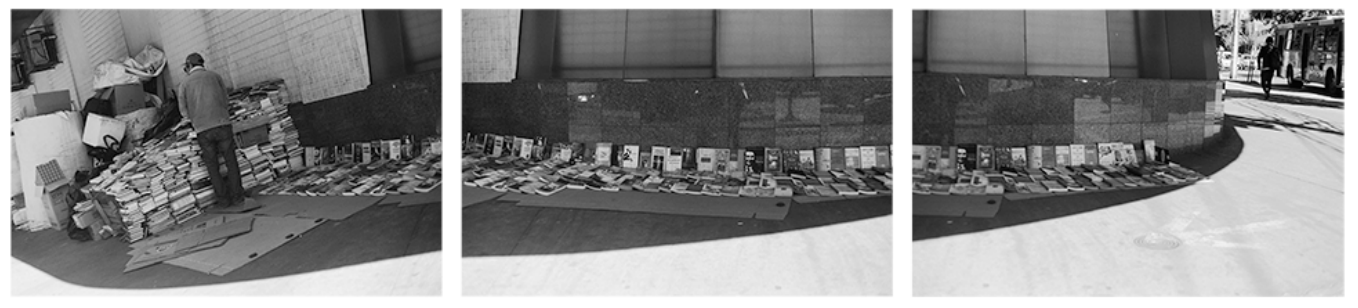

Figura 8. Da série "Desvios do descarte", com Odilon Tavares

Fotografias realizadas com câmera Nikon 80 e filme P\&B vencido, equipamento e material do acervo do Laboratório de Fotodocumentação Sylvio de Vasconcellos.

Fonte: Junia Mortimer, 2019.
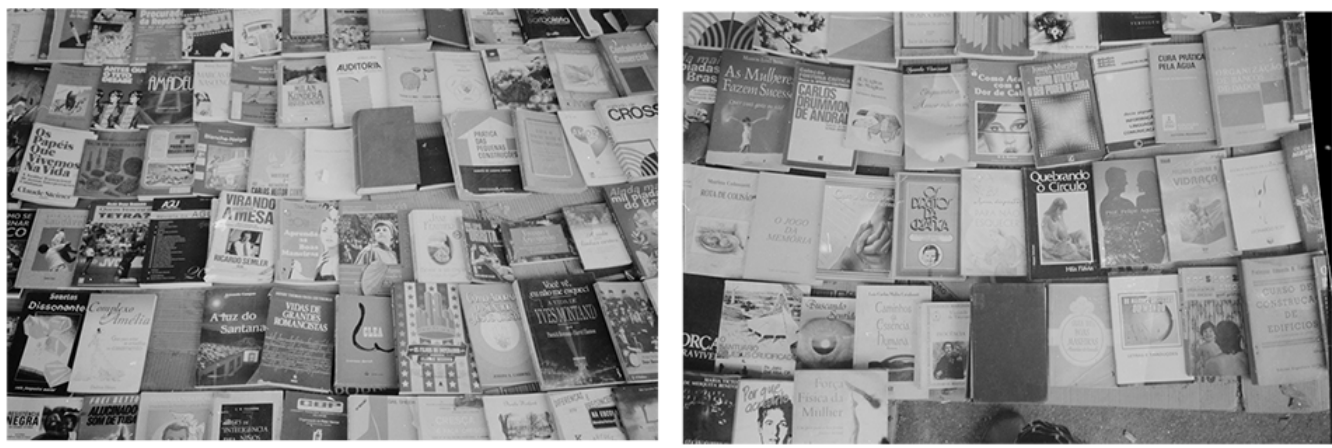

Figura 9. Da série "Desvios do descarte”, com Odilon Tavares

Fotografias realizadas com câmera Nikon 80 e filme P\&B vencido, equipamento e material do acervo do Laboratório de Fotodocumentação Sylvio de Vasconcellos.

Fonte: Junia Mortimer, 2019.

Na sala de fundo da Biblioteca Rafaelo Berti, da Escola de Arquitetura da UFMG, e na mesma cidade onde Odilon monta diariamente seu sebo, algumas estantes metálicas reúnem centenas de exemplares produzidos pelo Serviço Gráfico da Escola nas décadas de 1960 e 1970. Entre eles não há nenhum exemplar dos Documentários Arquitetônicos, que analisamos por meio do segundo gesto de pesquisa deste texto, mas há repetidas edições dos volumes V e VI da ambiciosa História da Arquitetura escrita por João Boltshauser, na década de 1960; há também exemplares repetidos de seus três volumes de Noções de evolução urbana das Américas; de Escultura ornamental barroca do Brasil, de Carlos del Negro; da 
apostila de Fluidotécnica, de Carvalho Lopes; entre outros. Periodicamente, as bibliotecárias depositam exemplares desse estoque na prateleira de descarte para os possíveis interessados.

Nas conversas com Odilon, fotografei-o, com sua permissão, usando câmeras e rolos de filme vencidos pertencentes ao antigo Serviço de Fotodocumentação; também utilizei a estrutura do Laboratório para revelar e ampliar essas imagens, as quais inseri em exemplares descartados pela Biblioteca. Levar esses livros, no fim de 2019, ao sebo de Odilon foi o gesto desta pesquisa por meio do qual a convergência entre as práticas, investigativa e urbana, se fez mais visível (Figura 10).
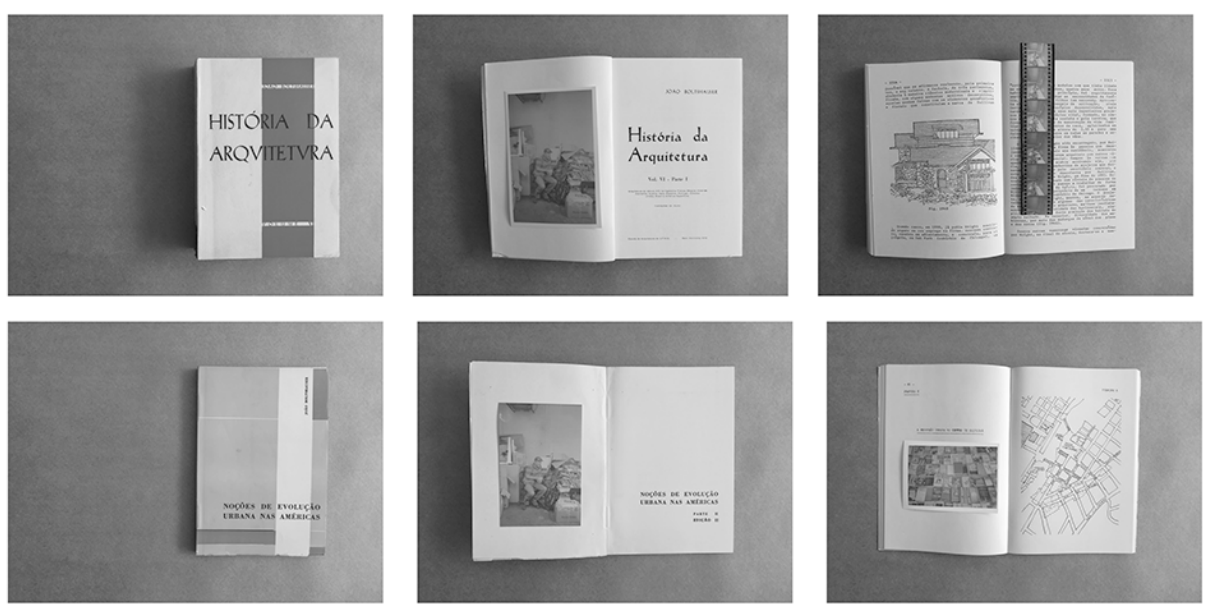

Figura 10. Da série "Desvios do descarte", com Odilon Tavares. Inserção das ampliações em livros excedente do Serviço Gráfico da Escola de Arquitetura da UFMG para doação ao acervo do livreiro de rua

Fonte: Junia Mortimer, 2019.

Em junho de 2020, em plena pandemia, Odilon teve grande parte de seu acervo de rua incendiado ${ }^{12}$. A comoção diante da violência do ato e do horror das imagens que circularam nas redes sociais incitou moradores a doar milhares de livros, contribuindo para a reparação do acervo do livreiro ${ }^{13}$. Além disso, uma parceria

12. Segundo a reportagem publicada no site da revista Encontro BH Cidade (disponível em: https://www.revistaencontro.com.br/canal/cidade/2020/o6/sebo-a-ceu-aberto-tem-livros-queimados-na-avenida-do-contorno.html), no dia 30 de junho de 2020, e também no site do jornal $O$ Tempo (disponível em: https://www.otempo.com.br/diversao/magazine/ambulante-que-fez-um-sebo-a-ceu-aberto-em-bh-tem-3-0oo-livros-queimados-1.2355037), do mesmo dia, Odilon teve seu acervo queimado no dia 27 daquele mês. Na ocasião, o livreiro perdeu cerca de 3 mil livros. Acessos em: 10 jul. 2020.

13. Segundo reportagens publicadas nos sites do jornal $O$ Tempo (disponível em: https://www. otempo.com.br/diversao/magazine/dono-de-sebo-que-teve-3-0oo-livros-queimados-ganha-o-triplo-em-48-horas-1.2355408) e também no do jornal Estado de Minas, (disponível em: https://www.em.com.br/ app/noticia/gerais/2020/07/01/interna_gerais,1161794/apos-incendio-dono-de-sebo-ao-ar-livre-de-bh-recebe-10-mil-doacoes.shtml), ambas do dia $1^{0}$ de julho de 2020, o livreiro recebeu em doações mais que 0 triplo do número de exemplares queimados, atingindo cerca de 10 mil volumes. 
entre Odilon Tavares, Marcos Franchini e Giulianno Camatta permitiu o desenvolvimento de um projeto, via financiamento coletivo, para garantir não somente condições de sobrevivência do acervo, como igualmente sua circulação e deslocamento em um sebo itinerante ${ }^{14}$. Conforme comentários que circularam nas redes sociais a propósito do acontecimento, esse movimento foi lido como uma ação coletiva que, se não resolve, pelo menos anima a encarar o que temos à nossa frente - no que concerne à onda de retrocesso e ignorância que, por vezes, parece acachapar nossas possibilidades inventivas.

\section{Conclusões}

A virada historiográfica possibilitada pelos arquivos - dentre outros aspectos epistemológicos - no campo da história da arquitetura e do urbanismo promoveu profundas mudanças nas décadas de 1980 e 1990 nos modos concernentes à compreensão das narrativas históricas já instituídas e à imaginação de outras, segundo as possibilidades dos documentos. Ao tratar de um arquivo fotográfico, incluindo fontes visuais e textuais, essa pesquisa se insere nesse movimento e busca, ao mesmo tempo, refletir sobre as práticas ou os gestos de pesquisa dentro de um arquivo, diante dos documentos, no intuito de fazê-los falar. Tensionam-se os limites disciplinares da história, da teoria e da estética por meio da construção de arranjos temporários e precários com diapositivos, ampliações fotográficas, cartas, livros e novos documentos produzidos ao longo da pesquisa, a fim de fazer emergirem questões referentes ao cotidiano, à técnica e à cidade, com especial atenção ao período entre 1950 e 1970. Situadas num arquivo fotográfico dedicado sobretudo à função de registro patrimonial, essas questões, já enfrentadas por outros pesquisadores, como Maria Cecília Londres e Silvana Rubino, põem em xeque as narrativas históricas em torno de monumento, memória e nação.

A pesquisa trouxe à tona conjuntos de diapositivos sem data e sem indexação arquivística que colocaram limites então difíceis de transpor para atingir desdobramentos historiográficos mais interessantes. As ampliações que propusemos objetivam evidenciar situações, olhares, sujeitos e gestos que descolam o registro patrimonial de seus roteiros oficiais para criar um ambiente urbano permeado por afetos, disputas, embates e também cuidados enquanto dimensão pública da cidade. Ao ampliar esses pequenos desvios fotográficos, talvez imprevistos ao olhar dos fotógrafos e inesperados para o pesquisador que se debruça sobre aque-

14. Sobre esse projeto de itinerância do sebo de Odilon, viabilizado por meio de financiamento coletivo, pode-se procurar mais informações na conta de Instagram "Sebo do Seu Odilon”. Disponível em: https://www.instagram.com/sebodoseuodilon/. Acesso em: 10 de julho de 2020 
le arquivo, desviamos do monumento arquitetônico como elemento patrimonial da nação para mostrar, de maneira fantasmática, a vida urbana, suas presenças e suas ausências.

Em termos de historiografia urbana, a pesquisa teve o propósito de lançar luzes sobre as lutas urbanas de fins da década de 1950 e início da de 1960 em Belo Horizonte, com base na análise das fotografias e dos textos da publicação Documentário Arquitetônico 3, resultado da parceria entre o Serviço de Fotodocumentação e o Serviço Gráfico da Escola de Arquitetura da UFMG. Ao inseri-la num emaranhado de acontecimentos e discursos, buscou-se evidenciar os limites e as possibilidades da imagem fotográfica no campo da história urbana, considerando o regime de visibilidade daquelas fotografias produzidas pelos profissionais do SFD. Entre o discurso higienista da assistente social do Departamento de Bairros Populares e Favelas e os excertos do livro Quarto de despejo, as fotografias e as legendas desse Documentário testemunham as contradições inerentes a um campo profissional em que, naquele momento, a presunção tecnocrática e a abordagem elitista entram em choque com a postura humanista e a apreciação genuína da invenção de estratégias espaciais (a poética do popular de Lina Bo Bardi [MORTIMER et al., 2018b]).

Por fim, pretendeu-se explorar também a atividade fotográfica como prática de pesquisa - fotografar como modo de pensar/fazer -, ao deslocar filmes, câmeras, tripés e outros dispositivos fotográficos do arquivo em estudo para o espaço cidade de Belo Horizonte. Além disso, foi ativada a estrutura da câmera escura, para a realização de revelações e ampliações que participaram desse gesto de desvio ao atribuir outros fins aos meios que se encontravam em desuso. Insisti na temática do cotidiano e da técnica a fim de atualizar a pesquisa historiográfica, situada nas décadas de 1950 e 1960, para um debate cultural em torno do descarte, da informalidade, da catação e da reciclagem na cidade contemporânea. Foram fundamentais para esse gesto de pesquisa a presença e a interlocução com o livreiro de rua Odilon Tavares.

Os gestos de pesquisa que exploramos nesse arquivo fotográfico lidam com a complexidade da fotografia, enquanto fonte visual ou modo de pensar/fazer, e evidenciam, como práticas urbanas, hábitos e formas de vida de temporalidades diversas. Apontam ainda para tensões disciplinares, possibilidades e limites teóricos, historiográficos e estéticos ao nos debruçarmos sobre a imagem no campo do urbanismo. Diante da fúria das imagens que caracterizam o momento contemporâneo (FONTCUBERTA, 2016, p. 260), esses gestos põe em cena reconfigurações de nossa habilidade de ver que podem se dar também por meio de práticas que remetem a um "des-ver”, seja na dimensão poética de Manoel de Barros, em Menino do mato (2013), seja na dimensão reflexiva tecida por Rita Velloso (2018) contra a espetacularização. 
Colocar-se diante de um arquivo fotográfico é estar diante de uma máquina de histórias. Ao encarar essa máquina, identificamos a lógica regente de sua estrutura, classificamos suas formas e funções, e perscrutamos em seus mistérios a reinvenção das imagens, a mostrar outras cidades. Retomando o conto de J. J. Veiga com que iniciamos este texto, pode-se dizer que essa máquina:

[...] já tem feito até milagre, mas isso - aqui para nós - eu acho que é exagero de gente supersticiosa, e prefiro não ficar falando no assunto. Eu - e creio que também a grande maioria dos munícipes - não espero dela nada em particular; para mim basta que ela fique onde está, nos alegrando, nos inspirando, nos consolando.

O meu receio é que, quando menos esperarmos, desembarque aqui um moço de fora, desses despachados, que entendem de tudo, olhe a máquina por fora, por dentro, pense um pouco e comece a explicar a finalidade da máquina, e para mostrar que é habilidoso (eles são sempre muito habilidosos) peça na garagem um jogo de ferramentas, e sem ligar a nossos protestos se meta por baixo da máquina e desande a apertar, martelar, engatar, e a máquina comece a trabalhar. Se isso acontecer, estará quebrado o encanto e não existirá mais máquina (VEIGA, 2008, s.p.).

\section{Referências}

AZOULAY, A. Potential history. Unlearning Imperialism. London; New York: Verso, 2019.

BARROS, M. Menino do mato. São Paulo: Alfaguara, 2013.

BARTHES, R. A preparação do romance. São Paulo: Martins Fontes, 2005. v. II. (Coleção Roland Barthes).

. A câmara clara: nota sobre a fotografia. Tradução de Júlio Castañon Guimarães. 7. ed. Rio de Janeiro: Nova Fronteira, 2018. (Clássicos de Ouro).

BENJAMIN, W. O anjo da história. Tradução de João Barrento. Belo Horizonte: Autêntica, 2012.

A obra de arte na época da possibilidade de sua reprodução técnica. In: Estética e sociologia da arte. Tradução: João Barrento. Belo Horizonte: Autêntica, $2017 a$.

Pequena história da fotografia. In: Estética e sociologia da arte. Tradução: João Barrento. Belo Horizonte: Autêntica, 2017b.

BRITO, J. G.; STRAMBI, A. O. Forros. Belo Horizonte: Escola de Arquitetura da Universidade de Minas Gerais, 1961. (Documentário Arquitetônico 4).

CADAVA, E. Words of light. Princeton: Princeton University Press, 1997.

CADAVA, E.; NOUZEILLES, G. The itinerant languages of photography. Princeton: Princeton University Press, 2014.

CARVALHO, V. C.; LIMA, S. F. Fotografia e cidade. São Paulo: Mercado de Letras: FAPESP, 1997. 
CASTRIOTA, L.; ÂNGELO, C. As dimensões de um arquivo: recuperando um patrimônio moderno. In: CASTRIOTA, L. Arquitetura e documentação. Belo Horizonte: Annablume, 2011. p. 145-168.

CERTEAU, M. de. A invenção do cotidiano: artes de fazer. 16. ed. Petrópolis: Vozes, 2009.

COLOMINA, B. Privacy and publicity: modern architecture as mass media. Cambridge: The MIT Press, 1996.

COSTA, E. A. Editorial. Cidade e cultura visual. Revista Urbana, Campinas, v. 9, n. 2, 2017 a. . Arquitetura e visualidade. São Paulo: Alameda, 2017b. . Arquivo, poder, memória. São Paulo: Alameda, 2018.

DIDI-HUBERMAN, G. Images in spite of all. Chicago: The University of Chicago Press, 2008. . O que vemos, o que nos olha. São Paulo: Editora 34, 2010. . Diante da imagem. São Paulo: Editora 34, 2013. . Montagem, remontagem (do tempo). Tradução: Milene Migliano. Horizonte: Chão da Feira, 2016. (Coleção Cadernos de Leitura). . Cascas. São Paulo: Editora 34, 2017 a. . Levantes. São Paulo: Editora Sesc, 2017b.

ESPADA, H.; ALONSO, A. Conflitos: fotografia e violência política no Brasil. São Paulo: Instituto Moreira Salles, 2018.

FARGE, A. O sabor do arquivo. São Paulo: EDUSP, 2017.

FONTCUBERTA, J. O beijo de Judas: fotografia e verdade. São Paulo: Gustavo Gili, 2010. . A câmera de Pandora: fotografia depois da fotografia. São Paulo: Gustavo Gili, 2012. . La furia de las imágenes: notas sobre la postfotografía. Barcelona: Galáxia Gutenberg, 2016.

JACQUES, P.; BRITTO, F. Gestos urbanos. Salvador, Edufba, 2017.

JESUS, C. M. de. Quarto de despejo: diário de uma favelada. 10. ed. Rio de Janeiro: Francisco Alves, 1983.

KNAUSS, P. O desafio de fazer História com imagens: arte e cultura visual. Artcultura, v. 8, n. 12, 2006.

KOSSOY, B. Fotografia e História. São Paulo: Ateliê Editorial, 2009.

MARQUEZ, R. Geografias portáteis: arte e conhecimento espacial. 2009. Tese (Doutorado) Instituto de Geociências, Universidade Federal de Minas Gerais, Belo Horizonte, 2009.

MAZZONI, G. T.; MAZZONI, M. de C. Favelas. Belo Horizonte: Serviço Gráfico da Escola de Arquitetura da Universidade de Minas Gerais, 1961. (Documentário Arquitetônico 3).

MELLO, S. Apresentação. In: MAZZONI, G. T.; MAZZONI, M. de C. Favelas. Belo Horizonte: Serviço Gráfico da Escola de Arquitetura da Universidade de Minas Gerais, 1961. (Documentário Arquitetônico 3). 
MENESES, U. B. de. Fontes visuais, cultura visual, história visual. Balanço provisório, propostas cautelares. Revista Brasileira de História, São Paulo, v. 23, n. 45, p. 11-36, 2003.

MENEZES, I. P. de. Fazendas mineiras. Acervo Curt Lange Belo Horizonte: Escola de Arquitetura da UFMG, 1969. (Documentário Arquitetônico 6).

MORTIMER, J. Arquiteturas do olhar. Belo Horizonte: C/Arte, 2017.

. Pensar por imagens. In: JACQUES, P; PEREIRA, M. Nebulosas do pensamento urbanístico. Salvador: Edufba, 2018a.

MORTIMER, J. et al. O popular em disputa: em torno de Lina Bo Bardi e Celso Furtado (19591964). In: ENCONTRO DA ASSOCIAÇÃO NACIONAL DE PESQUISA E PÓS-GRADUAÇÃO EM ARQUITETURA E URBANISMO, 5, 2018, Salvador. Anais [...]. Salvador: Edufba, 2018b. v. 2, p. 3590-3606.

MORTIMER, J.; SÁ, A. Cidade, técnica, cotidiano: trajetórias de Aracy Esteve Gomes e Lina Bo Bardi em Salvador. In: ENANPUR, 17., 2019, Natal. Anais [...] Natal: ANPUR, 2019. Tema: Tempos em/de transformação - utopias.

MORTIMER, J; DRUMMOND, W. (org.). Entre imagem e escrita: Aracy Esteve Gomes e Salvador. Salvador: Edufba, 2020 [no prelo].

MOURA, M. I. P. Primeiras casas de Belo Horizonte. Belo Horizonte: Escola de Arquitetura da Universidade de Minas Gerais, 1961. (Documentário Arquitetônico 5).

NAVAS, A. M. Fotografia e poesia (afinidades eletivas). São Paulo: Ubu, 2018.

NOUZEILLES, G. Os restos do político ou as ruínas do arquivo. In: SOUZA, E. M. de; MIRANDA, W. M. (org.). Crítica e Coleção. Belo Horizonte: Ed. UFMG, 2011.

. Arquitectura del fotolibro: escritura e imagen. Outra travessia: - Revista de Literatura do Programa de Pós-graduação em Literatura da UFSC, Florianópolis, n. 21, 2016.

OLIVEIRA, S. O movimento de favelas de Belo Horizonte e o Departamento de Habitações e Bairros Populares (1956-1964). Revista Mundos do Trabalho, v. 4, n. 7, p. 100-120, jan.-jun. 2012.

PINHEIRO, C. de V.; MAZZONI, G. T.; MAZZONI, M. de C. Alpendres. Belo Horizonte: Serviço Gráfico da Escola de Arquitetura da Universidade de Minas Gerais, 196o. (Documentário Arquitetônico 1).

SCHIAVINATTO, I. L. F.; COSTA, E. A. Cultura visual e História. São Paulo: Alameda, 2016.

SOMARRIBA, M. M. G.; VALADARES, M. G.; AFONSO, M. R. Lutas urbanas em Belo Horizonte. Petrópolis: Vozes; Belo Horizonte: Fundação João Pinheiro, 1984. 130 p.

STIERLI, M. Las Vegas in the rearview mirror: the city in theory, photography, and film. Los Angeles: Getty Publications, 2013.

. Montage and the metropolis. Architecture, Modernity, and the Representation of Space. New Haven; London: Yale University Press, 2018.

VEIGA, J. J. A estranha máquina extraviada: contos. 13. ed. Rio de Janeiro: Bertrand Brasil, 2008. 
VELLOSO, Rita. Modos de des-ver. Ou, a arquitetura experimentada depois da fotografia. Resenhas Online, São Paulo, ano 17, n. 194.03, fev. 2018. Disponível em: https://www.vitruvius.com.br/revistas/read/resenhasonline/18.194/6885. Acesso em: 10 maio 2020.

VIDLER, A. The spatial uncanny. In: CASEBERE, J. James Casebere. Milano: Edizioni Charta: Sean Kelly Gallery, 2001.

WASNER, M. E. Pavimentação. Acervo Curt Lange Belo Horizonte: Serviço Gráfico da Escola de Arquitetura da Universidade de Minas Gerais, 1960. (Documentário Arquitetônico 2).

WISNIK, G. Dentro do nevoeiro. São Paulo: Ubu, 2019.

ZIMMERMAN, C. Modern architecture between photography and image. Beijing: Urban Environment Design, 2012a. p. 66-71.

. Photography into building in postwar architecture: The Smithsons and James Stirling. Art History, v. 2, p. 270-287, 2012b. DOI: 10.1111/j.1467-8365.2011.00886.x.

Photographic architecture in the twentieth century. Minneapolis: University of Minnesota Press, 2014. 


\section{Junia Cambraia Mortimer}

Graduada em Arquitetura e Urbanismo pela Escola de Arquitetura da Universidade Federal de Minas Gerais (2007). Mestre em Artes e Humanidades (2010) pela Universidade Nova de Lisboa, em Portugal, pela Universidade de Perpignan, na França, e pela Universidade de Sheffield, na Inglaterra (programa Erasmus Mundus). Doutora em Arquitetura e Urbanismo (2015) pelo Programa de Pós-graduação em Arquitetura e Urbanismo da UFMG (NPGAU), com estágio sanduíche na Cooper Union, em Nova York, sob orientação de Anthony Vidler. Realizou pós-doutorado (2019) na Escola de Arquitetura da UFMG, sob tutela de Renata Marquez. É professora da Faculdade de Arquitetura da Universidade Federal da Bahia (UFBA) e professora permanente do Programa de Pós-graduação em Arquitetura e Urbanismo (PPGAU) e do Programa de Pós-graduação em Artes Visuais (PPGAV), ambos dessa instituição.

Email: junia.mortimer@ufba.br

ORCID: 0000-0001-7939-5110

Submissão: 21 de maio de 2020.

Aprovação: 22 de setembro de 2020.

Como citar: MORTIMER, J. C. Poéticas de arquivo como práticas urbanas: três gestos de pesquisa no arquivo do Laboratório de Fotodocumentação Sylvio de Vasconcellos. Revista brasileira de estudos urbanos e regionais. v. 22, e202039pt, 2020. DOI 10.22296/2317-1529. rbeur.202039pt

Artigo licenciado sob Licença Creative Commons CC BY 4.0. https://creativecommons.org/licenses/by/4.o/deed.pt_BR 